\title{
Inhibition of Brain Protein Synthesis by Cycloheximide Does Not Affect Formation of Long-Term Memory in Honeybees after Olfactory Conditioning
}

\author{
Susanne Wittstock, ${ }^{1}$ Hans-Hinrich Kaatz, ${ }^{2}$ and Randolf Menzel' \\ 'Institut für Neurobiologie, Freie Universität Berlin, 1000 Berlin 33 and '2Zoologisches Institut, Entwicklungsphysiologie, \\ Universität Tübingen, 7400 Tübingen, Germany
}

\begin{abstract}
The honeybee forms a long-term memory in different training situations that lasts for a lifetime, but the cellular mechanisms of long-term memory formation are not known. We analyzed the dependency of long-term memory on the de novo brain protein synthesis. The protein synthesis inhibitor cycloheximide was injected via the median ocellus directly into the brain. ${ }^{3} \mathrm{H}$-leucine incorporation into brain proteins was inhibited by $>95 \%$ for $>3 \mathrm{hr}$. The time of protein synthesis inhibition was prolonged by a second injection of the same dose. Worker honeybees were conditioned to an olfactory stimulus at different times before and after injection. The proboscis extension response (PER) of bees restrained in tubes was classically conditioned with sugar water applied first to the antennae followed by feeding (unconditioned stimulus) paired with odor presentation (conditioned stimulus). The bees were tested by presenting the odor alone at different times up to $\mathbf{2 4} \mathrm{hr}$ after injection. No significant reduction in the probability of the conditioned response in cycloheximide-treated bees was found when compared to the Ringer-injected controls in 4 series of experiments. Since protein synthesis was inhibited between $7 \mathrm{hr}$ pre- and $7 \mathrm{hr}$ postconditioning without affecting the formation of long-term memory, a possible role of de novo protein synthesis in the formation of long-term memory after olfactory conditioning of the PER is not supported by these experiments.
\end{abstract}

[Key words: insect, honeybee, learning and memory, olfactory conditioning, cycloheximide, inhibition of protein synthesis]

In recent decades it has been shown in a number of studies using different species that inhibition of brain protein synthesis leads to a reduction in formation of long-term memory (LTM) (Flexner et al., 1965, 1967; Agranoff et al., 1966; Barondes and Cohen, 1967; Hyden and Lange, 1970; Squire and Davis, 1975; Davis et al., 1976). In vertebrates, different inhibitors of protein synthesis such as puromycin, cycloheximide, or anisomycin distort the formation of a long-lasting memory if they are applied shortly before or after training (Squire and Barondes, 1974;

Received Jan. 13, 1992; revised June 8, 1992; accepted Sept. 15, 1992.

This work was supported by the Deutsche Forschungsgemeinschaft. We thank Wolf Engels, Tim Tully and Juliane Mauelshagen for their comments on the manuscript.

Correspondence should be addressed to Dr. Susanne Wittstock, Institut für Neurobiologie, Freie Universität Berlin, Königin-Luise-Strasse 28/30, 1000 Berlin 33, Germany.

Copyright (c) 1993 Society for Neuroscience $0270-6474 / 93 / 131379-08 \$ 05.00 / 0$
Flood et al., 1975a,b; Gibbs and Ng, 1977; Eisenstein et al., 1983).

The notion that the formation of LTM depends on protein synthesis was also supported by recent studies of invertebrate learning and memory. These experiments strongly suggest the relationship of LTM to protein synthesis on the basis of cellular and molecular studies. Montarolo et al. (1986) showed that in Aplysia, long-term (but not short-term) facilitation induced by the application of 5-HT requires protein synthesis, and Eskin et al. (1989) found that the incorporation of labeled amino acids into proteins was changed in pleural sensory neurons of Aplysia after treatments of 5-HT. Alkon et al. (1987) demonstrated in Hermissenda that the $\mathrm{Ca}^{2+}$-mediated reduction of $\mathrm{K}^{+}$currents, which is, on the behavioral level, an essential component of the conditioned response, can be prevented by protein synthesis inhibitors. Crow and Forrester (1990) showed that long-term enhancement of light-evoked generator potentials in B photoreceptors produced by one-trial conditioning was blocked by protein synthesis inhibition. Recently, another kind of longterm plasticity, long-term adaptation at the crayfish neuromuscular junction, was found to depend on protein synthesis (Nguyen and Atwood, 1990).

There are, however, different hypotheses regarding the functional role of protein synthesis. In Aplysia, for example, it is evident that protein synthesis during long-term facilitation is necessary for a persistent change of the regulatory subunits of the cAMP-dependent protein kinase (Bergold et al., 1990). Other studies emphasize that training is responsible for structural changes of synapses that depend on protein synthesis (Fifkova and van Harreveld, 1978; Fifkova et al., 1982; Bailey and Chen, 1983, 1988; Patel and Stewart, 1988; Patel et al., 1988). In the honeybee, such learning-dependent structural changes also may have been observed. Brandon and Coss (1982) reported that the shapes of spines of mushroom body intrinsic neurons were changed after the first orientation flight of young honeybees. Since proper controls are missing, it is not yet clear whether the formation of a stable LTM requires de novo protein synthesis in honeybees.

During the last few years, detailed information about the temporal dynamics underlying the formation of a stable LTM for food-rewarded odorants has been acquired (Menzel, 1990). Freeflying honeybees quickly learn (within one or a few trials) to return to a food mark and can remember it for a lifetime (von Frisch, 1922; Lindauer, 1963; Menzel, 1968). Also, under restrained conditions [the proboscis extension response (PER) conditioning], appetitive odor learning takes place quickly and 
leads to a stable associative memory that lasts for as long as the bees survive in the tube (Kuwabara, 1957; Vareschi, 1971; Menzel et al., 1974; Menzel, 1990). Amnestic treatments have shown that the consolidation of LTM is located predominantly in the paired mushroom bodies of the protocerebrum (Menzel et al., 1974; Masuhr, 1976; Erber et al., 1980).

Since PER conditioning leads to an olfactory LTM passing through stages of short-term and intermediate-term memory, we hypothesize that protein synthesis in the brain is necessary for LTM formation. Therefore, protein synthesis was blocked by a protein synthesis inhibitor at different times before and after conditioning. The blocking agent was injected directly into the brain to achieve the most effective inhibition of protein synthesis and to avoid possible side effects of the blocker. The conditioning procedure allowed controlled variations of the temporal succession of conditioning, blocking period, and test time. The injection of the inhibitor directly into the brain keeps the viability of the test animals high, since they survive equally long as the control animals and show no signs of discomfort. The memory tests were performed up to $24 \mathrm{hr}$ after conditioning because earlier studies indicated that LTM determines memory performance at time intervals longer than several hours (Menzel, 1990). The results indicate that LTM formation is not reduced although protein synthesis is blocked at a level of $>95 \%$. The procedure applied in this study follows exactly the techniques that in the past led to positive results in other animals. In an independent study (T. Tobin and B. Smith, personal communication), similar questions were investigated using a different experimental arrangement, and the same conclusion was reached.

\section{Materials and Methods}

\section{Protein synthesis}

Animals. Foraging worker bees (Apis mellifera) were used for all analyses. The animals were caught at the hive entrance on their way out for foraging.

Materials. Cycloheximide (Sigma Chemical Co., Munich, Germany) was dissolved in Tris buffer ("bee Ringer"; $80 \mathrm{~mm}$ Tris, $135 \mathrm{~mm} \mathrm{NaCl}$, $5 \mathrm{~mm} \mathrm{KCl}, 10 \mathrm{~nm} \mathrm{MgCl}_{2}, 16 \mathrm{~nm} \mathrm{CaCl}_{2}$ ) at $\mathrm{pH} 7.25$. 1-4,5-3 $\mathrm{H}$-leucine (Amersham-Buchler, Braunschweig, Germany; specific activity, 5.22 $\mathrm{TBq} / \mathrm{mmol}$ ) was diluted in bee Ringer to a final concentration of radioactivity of $111 \mathrm{MBq} / \mathrm{ml}$.

Determination of tracer incorporation into brain proteins. The level of protein synthesis in the brain of worker bees was measured by the incorporation of ${ }^{3} \mathrm{H}$-leucine into trichloroacelic acid (TCA)-precipitable polypeptides. In initial experiments, this tracer proved to be superior to ${ }^{35} \mathrm{~S}$-methionine and a mixture of 15 tritiated amino acids for measuring brain protein synthesis. We chose the former since it resulted in higher and more constant incorporation rates than the latter. The level of protein synthesis inhibition after cycloheximide treatment (see below), however, proved to be the same (>95\%) irrespective of the labeled amino acids tested.

The bees received $300 \mathrm{nl}$ injections of ${ }^{3} \mathrm{H}$-leucine directly into the brain via the median ocellar tract as described below for cycloheximide injections. Water-soluble substances injected by this method spread rapidly (within a few minutes) across the entire brain as shown both by dye injections and by the resultant effects of injected transmitters or modulators on the behavior of the animal (Menzel et al., 1988, 1990; Michelsen, 1988). After defined periods of tracer incorporation, the bees were immobilized with $\mathrm{N}_{2}$. First, hemolymph samples of $2 \mu \mathrm{l}$ were taken from an abdominal incision in the third tergite. Second, the brains were freed of adhering tracheae and surrounding exocrine glands and, after several washes with bee Ringer, were dissected from the head capsules. The hemolymph was used to determine the amount of free labeled leucine, which equilibrated between brain and hemolymph within 3-5 min, remained nearly stable for about $90 \mathrm{~min}$, and decreased only slightly. Treated and untreated bees did not differ in this respect. The brains were immediately placed into a $1 \mathrm{ml}$ tissue grinder containing $40 \mu \mathrm{l}$ of ice-cold phosphate-buffered saline (PBS; $0.04 \mathrm{M}, \mathrm{pH}$ 6.7). Each brain was manually homogenized and was transferred to a centrifuge tube. The homogenizer was rinsed twice with $40 \mu$ l of PBS. The tubes were spun at $10,000 \times g$ for $10 \mathrm{~min}$. The pellet was discarded and the supernatant containing, among others, the water-soluble brain proteins was stored at $-30^{\circ} \mathrm{C}$ pending further analyses.

Later, each supernatant was divided into two aliquots. For determination of protein synthesis, one aliquot was applicd to a $15 \times 15$ mm cellulose filter paper (Macherey \& Nagel, MN 214) and air dried. Proteins were precipitated on the filter paper with ice-cold TCA $(10 \%$, w/v). After several washes (see Kaatz et al., 1985, for details), the precipitated proteins were dissolved with a quaternary ammonium hydroxide base and bound label was quantified by liquid scintillation counting (LSC). Tracer incorporation was expressed as dpm/brain and adjusted for background, unspecific binding of ${ }^{3} \mathrm{H}$-leucine to the filter paper, and for decays.

Counting efficiency was determined by the analysis of the spectral quench parameters of the isotope. The success of each tracer injection was controlled by measuring via LSC the total amount of label present in the other aliquot of the brain homogenate and in the $2 \mu \mathrm{l}$ hemolymph samples of each bee as well. Additionally, the total tracer content in the brain was used. ${ }^{3} \mathrm{H}$-leucine binds to the filter paper by about $0.3 \%$, dependent on its radioactive concentration (correlation coefficient $r=$ $0.994)$. This non-protein-bound activity of the tracer was subtracted from the activity measured with the former aliquot, resulting in the specifically protein-bound labeled leucine.

The level of protein synthesis inhibition in the brain was measured by injecting cycloheximide, an antibiotic that blocks translation of RNA. The concentrations chosen were determined by dose-response analysis beginning with the highest concentration of cycloheximide $\left(5 \times 10^{-2}\right.$ M) soluble in bee Ringer, and continuing with the next four lower orders of magnitude. The former concentration corresponds to $4.2 \mu \mathrm{g}$ cycloheximide per injection volume of $300 \mathrm{nl}$ and amounts to a dosage of $42 \mathrm{mg}$ cycloheximide/ $\mathrm{kg}$ body weight, since a bee weighs about $100 \mathrm{mg}$. After the injection of different dosages of cycloheximide and subsequent injections of tracer, a $45 \mathrm{~min}$ period of traccr incorporation followed. The latter period resulted from experiments on the kinetics of tracer incorporation (Fig. 1) and was chosen for all experiments on cycloheximide effects. Linear ${ }^{3} \mathrm{H}$-leucine incorporation occurred within less than 5 min without an apparent lag phase, indicating an immediate tracer transfer into the brain cells, and lasted for at least $90 \mathrm{~min}$ in vivo. The percentage of inhibition of ${ }^{3} \mathrm{H}$-leucine incorporation by cycloheximide was calculated by comparing incorporation in drug-treated brains with that in bee Ringer-treated brains. Cycloheximide seemed to spread rapidly across the whole brain, since we initially found that protein synthesis inhibition, as well, is strongly inhibited in the optic lobes $(92.6 \%, n=6)$, which are farthest from the injection site.

\section{Behavioral studies}

Preparation of animals. In the late afternoon of the day before the experiment, bees, departing for a foraging trip, were caught at the hive entrance. They were immobilized for a short time on ice cubes and mounted in metal tubes by a strip of tape between head and thorax. This fixation allowed free movement of the mouthparts and antennae.

The bees were fed to satiation with sucrose solution $(1 \mathrm{M})$ and kept overnight in a dark box in a humid and cool climate. They were removed from the box $1 \mathrm{hr}$ before the experiment started. Half an hour later each animal was fed with a small drop of sucrose solution to ascertain that each experimental animal showed the proboscis extension reflex to sucrose, and to check that the proboscis was not squeezed between the body and the tube wall.

Injection. The injections of cycloheximide and bee Ringer via the bees' ocelli were performed with a spccially developed glass capillary syringe, which enabled accurate injections in the nanoliter range (Michelsen and Menzel, 1984).

Conditioning and tests. Each bee was subjected to a classical conditioning procedure. Thereby, sucrose solution serves as the unconditioned stimulus (US), which by contacting the antennae elicits extension of the proboscis [unconditioned response (UR)]. An odor stimulus (carnation) serves as the conditioned stimulus (CS). The onset of odor stimulation precedes the onset of the US by $3 \mathrm{sec}$ and fully overlaps with the US. Compared to the classical conditioning procedure usually applied (Kuwabara, 1957; Vareschi, 1971; Menzel et al., 1974; Bitterman et al., 1983), the simultaneous presentation of CS and US was extended to 5 sec, during which the bee was allowed to imbibe the sucrose solution. It was necessary to extend the time allowed for feeding 


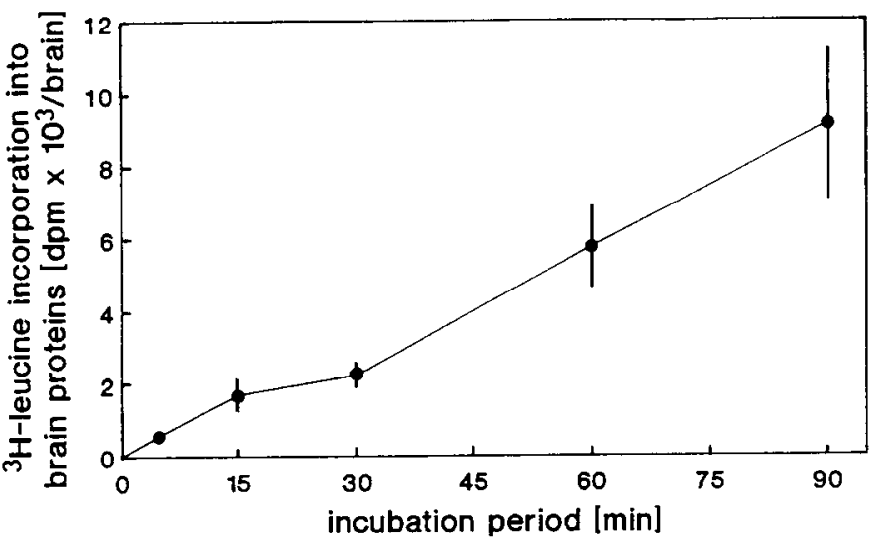

Figure 1. Kinetics of tracer incorporation into brain proteins of foraging bees. After direct ${ }^{3} \mathrm{H}$-leucine injection into the brain and different incubation periods, tracer incorporation into water-soluble brain proteins was measured after TCA precipitation. The data points give the means $\pm \mathrm{SE}$ for $n=6-14$

during a conditioning trial to reduce the number of additional feedings outside the conditioning procedure. Only one additional feeding was necessary during the experiment to minimize mortality due to starvation. Even with 2 conditioning trials, extended licking time was not sufficient to satiate the animals, which might reduce the $C R$ as a result of decreased motivation (Menzel, 1990). Menzel and Erber (1972) have shown that the duration of feeding during the first few trials of conditioning has no effect on acquisition.

During the tests, the odor stimulus (CS) was presented alone, which, in case of successful conditioning, elicited proboscis extension. Each bee was tested at different times after 2 conditioning trials. Repetitive testing at intervals in the range of hours does not cause any significant extinction. Therefore, the test procedure applied here offers the advantage of collecting a large number of test responses at various intervals over a $24 \mathrm{hr}$ range.

Data analysis. The learning rate was defined as the ratio between the number of animals that showed proboscis extension to the test odor stimulus and the overall number of animals tested at this time. In all tests, we counted only those animals that survived the whole test period of $24 \mathrm{hr}$. Since the few bees $(<10 \%)$ that responded to the CS prior to the conditioning trials were excluded from the conditioning procedure, the response rate is equivalent to the learning rate. The learning rate always exceeds $50 \%$; therefore, no statistical evaluation was necessary to test for the learning effect. Learning under these conditions is purely associative (Bitterman et al., 1983; Menzel et al., 1990). The associative effects are so compelling and well established that additional control groups (e.g., forward pairing) were not necessary.

The $\chi^{2}$ test was uscd to examine the data for statistically significant differences between the experimental group and the Ringer-injected group.

Toxicity of cycloheximide. Cycloheximide is a highly toxic substance in many animals (Bennett et al., 1972), though minimal mortality from drug application has also been observed (Barraco et al., 1981). However, cycloheximide directly injected into the brain of the honeybee did not create apparent lethal or toxic effects. Several hundred animals were observed in paired groups (cycloheximide or Ringer injected) over periods of $>24 \mathrm{hr}$ and no difference $\left(\chi^{2}\right.$ test) was found with respect to mortality, response to sucrose solution, and other behavioral responses (sucking and licking, antennal response, olfactory conditioning). It is thus concluded that the viability of the test animals is not affected by a cycloheximide injection.

\section{Results}

Protein synthesis

Inhibition of brain protein synthesis by cycloheximide. In a first series of experiments, the dosage of cycloheximide that enabled highest inhibition of protein synthesis was determined. Injection of $4.2 \mu$ g cycloheximide ( $42 \mathrm{mg} / \mathrm{kg}$ body weight) led to $97 \pm$ $1 \%( \pm \mathrm{SE})$ inhibition of the synthesis of water-soluble, TCAprecipitable proteins in the bee brain (Table 1). All other dosages
Table 1. Dose-dependent inhibition of protein synthesis by cycloheximide in brains of worker bees

\begin{tabular}{llll}
$\begin{array}{l}\text { Dose of cycloheximide } \\
\text { injected }(\mathrm{gm})\end{array}$ & $n$ & $\begin{array}{l}\text { Tracer } \\
\text { incorporation } \\
\text { mean } \pm \text { SE } \\
(\mathrm{dpm})\end{array}$ & $\begin{array}{l}\text { Inhibition } \\
\text { of protein } \\
\text { synthesis } \\
(\%)\end{array}$ \\
\hline $4.2 \times 10^{-6}$ & 16 & $186 \pm 78$ & 96.7 \\
$4.2 \times 10^{-7}$ & 11 & $1176 \pm 320$ & 79.8 \\
$4.2 \times 10^{-8}$ & 13 & $1720 \pm 302$ & 70.0 \\
$4.2 \times 10^{-9}$ & 16 & $2120 \pm 430$ & 63.0 \\
0 (control, Ringer injected) & 37 & $5732 \pm 682$ & 0.0
\end{tabular}

Bees were injected directly into the brain with 300 nl of bee Ringer containing defined doses of cycloheximide. After $2 \mathrm{hr}$ of drug exposure, $300 \mathrm{nl}$ of ${ }^{3} \mathrm{H}$-leucine $(0.9 \mu \mathrm{Ci})$ was injected. Tracer incorporation was terminated after $45 \mathrm{~min}$. The highest dose corresponds to $0.05 \mathrm{~m}$ cycloheximide.

were considered unsuitable for ongoing experiments, since the resulting inhibition was below $80 \%$.

Next, the duration of the inhibitory effect of $4.2 \mu \mathrm{g}$ cycloheximide on protein synthesis was determined. With this dosage, the maximal level of inhibition is maintained for about $4 \mathrm{hr}$ post cycloheximide injection (Table 2). Five hours after cycloheximide injection, inhibition continues at $90 \%$. Based on these results, experiments were designed that guaranteed maximal inhibition during the period of learning, of memory consolidation, and of memory tests.

\section{Behavioral experiments}

Single cycloheximide injection after conditioning. First we tested whether the formation of LTM could be impaired by application of cycloheximide at a definite period after undisturbed learning. The injection times of the 6 experimental arrangements were set to cover a period between $45 \mathrm{~min}$ and $3 \mathrm{hr}$ after conditioning.

Only those animals that, after conditioning, responded with proboscis extension to the CS alone (i.e., > 80\%) were selected for injection. This means that the learning rate (CR) in both groups was $100 \%$ before injection. In the first test after injection, the learning rates (CR) of both the cycloheximide-treated and Ringer-injected bees are relatively high (only one group less than $80 \%$ ), which demonstrates that the injection itself does not have

Table 2. Duration of inhibitory action of cycloheximide on protein synthesis in brains of worker bees

\begin{tabular}{lccc}
$\begin{array}{l}\text { Duration of exposurc } \\
\text { to cycloheximide } \\
\text { (min) }\end{array}$ & $n$ & $\begin{array}{l}\text { Tracer } \\
\text { incorporation } \\
\text { mean } \pm \text { SE } \\
(\mathrm{dpm})\end{array}$ & $\begin{array}{l}\text { Inhibition of } \\
\text { protein synthesis } \\
(\%)\end{array}$ \\
\hline Control & 21 & $5978 \pm 971$ & 0.0 \\
5 & 8 & $224 \pm 119$ & 95.9 \\
15 & 7 & $162 \pm 68$ & 97.3 \\
45 & 6 & $34 \pm 14$ & 99.4 \\
90 & 8 & $346 \pm 165$ & 94.2 \\
135 & 6 & $188 \pm 75$ & 96.9 \\
180 & 5 & $370 \pm 174$ & 93.8 \\
240 & 8 & $618 \pm 191$ & 89.7
\end{tabular}

After defined periods of exposure to $4.2 \mu \mathrm{g}$ cycloheximide $(0.05 \mathrm{~m}), 300 \mathrm{nl}$ of ${ }^{3} \mathrm{H}-$ leucine $(0.9 \mu \mathrm{Ci})$ was injected. Tracer incorporation was measured after $45 \mathrm{~min}$ of incubation. For controls, bees were injected with $300 \mathrm{nl}$ of bee Ringer and incubated for 5,90 , or $240 \mathrm{~min}$ before tracer injection. Since the three groups did not differ significantly ( $F$ and $t$ test, $p<0.01$ ), their data for total tracer incorporation were combined. 


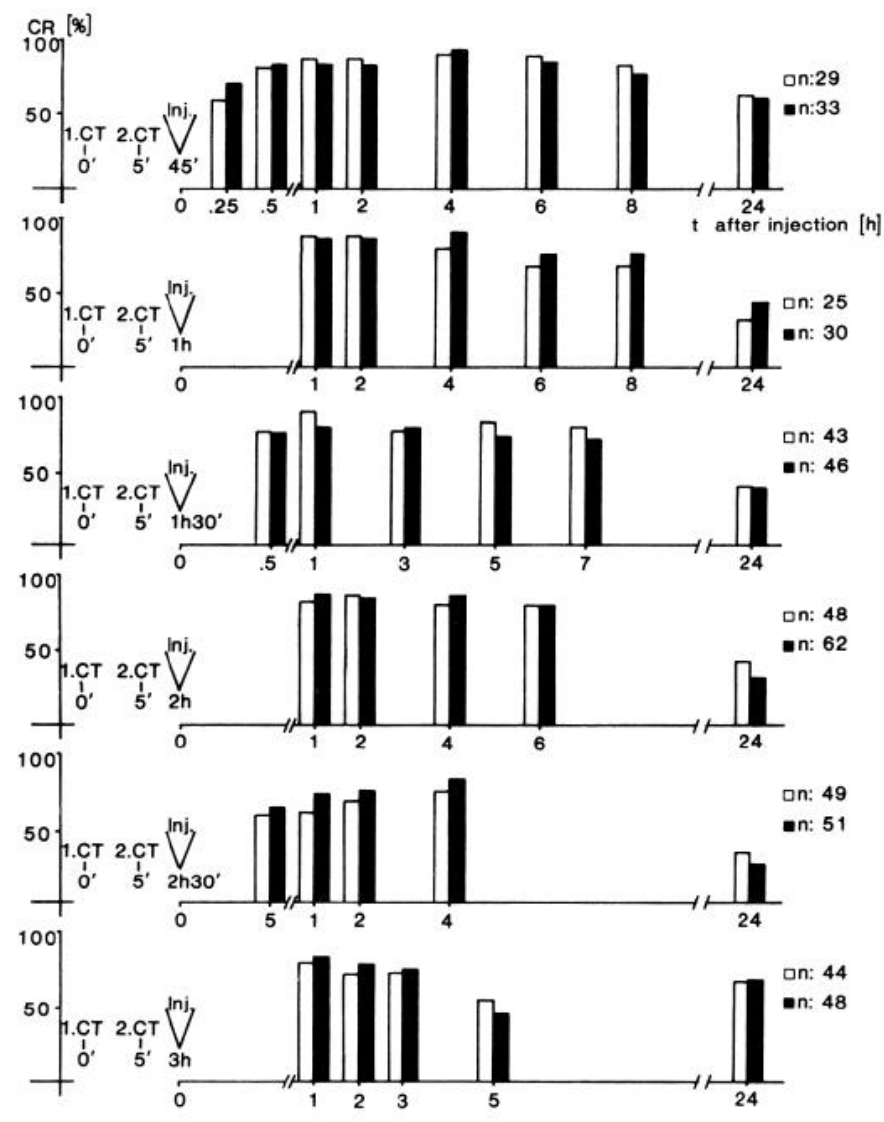

Figure 2. Single cycloheximide injection after conditioning: CR of cycloheximide-injected bees $(\square)$ and Ringer controls $(\square)$ at different times after injection. The period between two conditioning trials (1.CT, 2.CT) and injection (Inj.) differed between $45 \mathrm{~min}$ and $3 \mathrm{hr}$ in six different experiments. Each bee was tested at different times. The time of injection is given with respect to time of conditioning.

a significant distorting effect on the recall of the conditioned odor response (Fig. 2). For the $24 \mathrm{hr}$ test response, a decreased $\mathrm{CR}$ is observed. Since this is true for both test groups, this effect cannot be referred to the protein synthesis inhibitor. At any test time, in all experimental groups, no significant differences between the 2 groups could be observed ( $\chi^{2}$ test). Therefore, cycloheximide does not have a distorting effect on the recall of the conditioned odor response. It should be mentioned here again that the survival rate of animals was not reduced after injection of cycloheximide (see Materials and Methods).

Single cycloheximide injection before conditioning. To test whether the treatment with the protein synthesis inhibitor before conditioning would influence the $\mathrm{CR}$, cycloheximide was injected before training. In 5 experimental groups, the time between injection and the first of 2 conditioning trials was varied between $3 \mathrm{hr}$ and $50 \mathrm{~min}$. Each animal was tested six or seven times up to $24 \mathrm{hr}$ after conditioning. For each test, the CR of the cycloheximide-injected bees was compared to both the Ringer-injected and the noninjected control groups (Fig. 3).

There are no significant differences between the CR of cycloheximide-injected bees and the Ringer control animals. Only in one case (injection $2 \mathrm{hr} 10 \mathrm{~min}$ before first trial, tested $6 \mathrm{hr}$ later) was the $\mathrm{CR}$ of cycloheximide-treated bees significantly higher than that of the Ringer controls. However, this observed difference contradicts the hypothesis that the protein synthesis inhibitor leads to a decreased rather than an increased CR level.

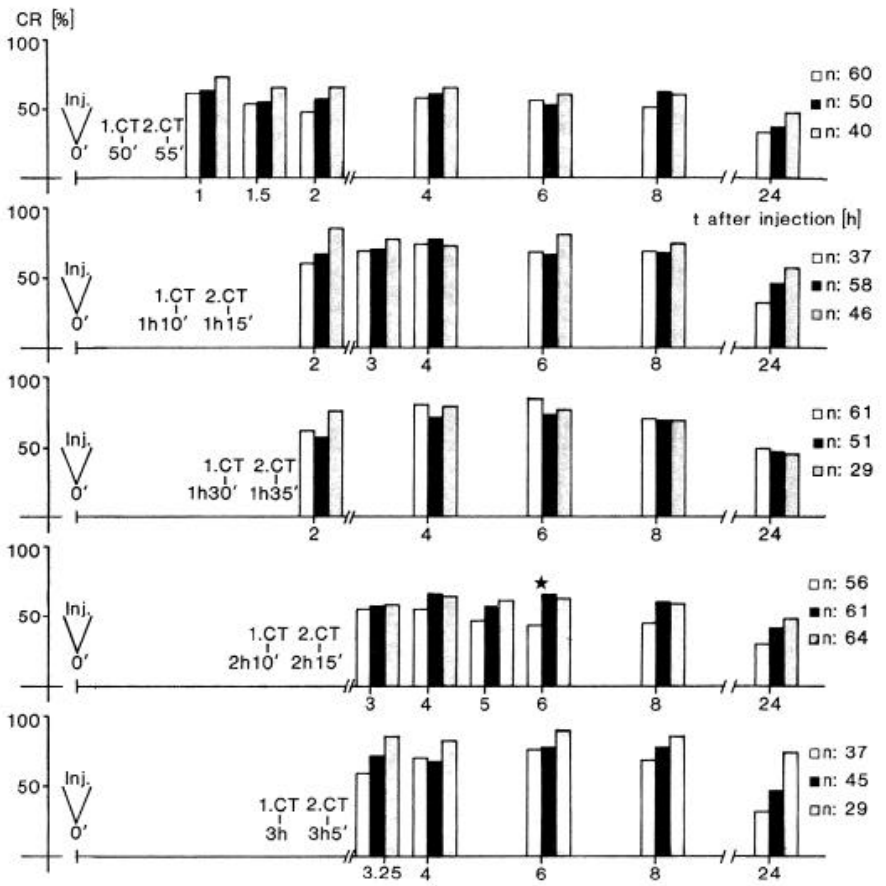

Figure 3. Single cycloheximide injection before conditioning: CR of cycloheximide-injected bees (black bars), Ringer controls (white bars), and noninjected animals (gray bars) at different times after injection. The period between injection (Inj.) and two conditioning trials (1.CT, 2.CT) differed between $50 \mathrm{~min}$ and $3 \mathrm{hr}$ in five experiments. Each bee was tested at different times. The time of conditioning is given with respect to time of injection. $\star, p<0.05, \chi^{2}$ test.

Thus, with one exception, the CR of the noninjected control group is not different from the CR of the injected groups. These results demonstrate that the injection itself has no negative effect, either on conditioning or on memory formation. Obviously, for the experimental group with the longest time interval between injection and training, the decrease of the CR with time after conditioning is much less pronounced than for the noninjected group. The learning rates of both injected groups are relatively high for the first test (60-80\%), regardless of the time of injection. The decrease of the CR at the longest interval (24 $\mathrm{hr}$ ) is a common phenomenon known from other learning studies in bees (Menzel, 1990).

It can be summarized for this experimental series that the treatment with cycloheximide during a period of $3 \mathrm{hr}$ to $50 \mathrm{~min}$ before training does not have an inhibitory influence on the CR.

Double injection of cycloheximide before conditioning. The argument that a high protein synthesis inhibition did not endure long enough before training should be examined by these experiments. A second injection of the protein synthesis inhibitor should extend the effective inhibition period of the first injection. Four experimental groups were injected twice with an interval of 3-4 hr between the injections. The time elapsing between injection and training was varied for the four groups, maximally $7 \mathrm{hr}$ between first injection and conditioning. After the two learning trials, the bees were tested twice, the first taking place $1 \mathrm{hr}$ after conditioning and the second $24 \mathrm{hr}$ after the first injection. The results are illustrated in Figure 4. Both groups, the cycloheximide-injected and saline control animals, show an overall lower CR (in the first tests maximal 60\%) than in the experimental series with only 1 injection. Thus, this must be 


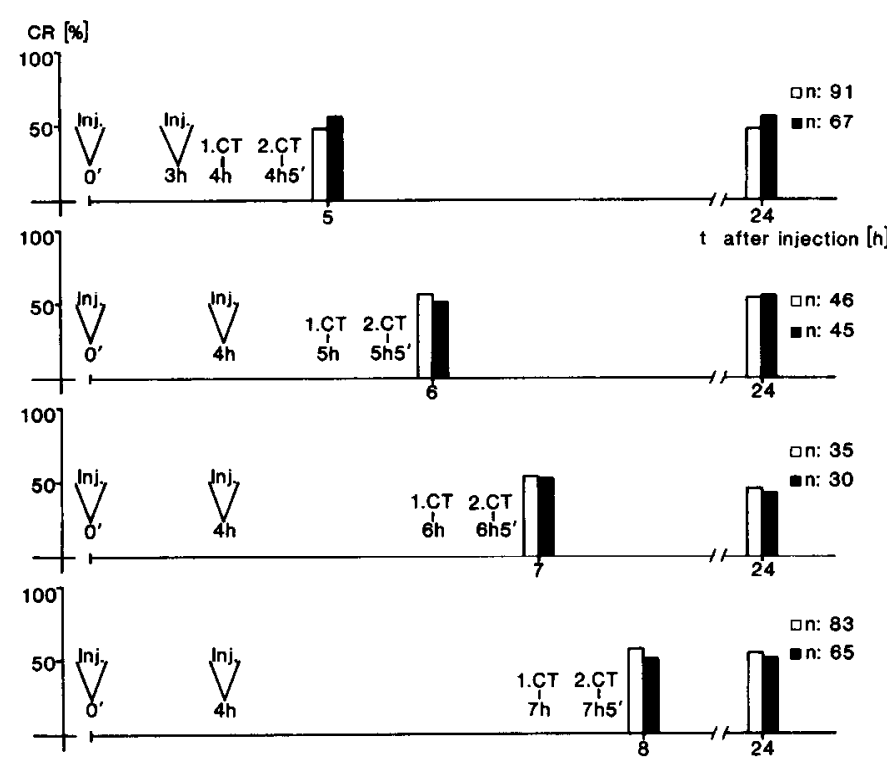

Figure 4. Double injection of cycloheximide before conditioning: $\mathrm{CR}$ of cycloheximide-injected bees $(\square)$ and Ringer controls $(\square)$ at different times after (the first) injection (Inj.). The period between the first injections was 3 or $4 \mathrm{hr}$. The period between the first injection and conditioning $(1 . C T, 2 . C T)$ differed between $4 \mathrm{hr}$ and $7 \mathrm{hr}$ in four experiments. The time of the second injection and conditioning is given with respect to time of the first injection. Each bee was tested at different times.

interpreted as an effect of the injection itself. At no time are there significant differences between the two groups.

Therefore, even two subsequent injections of cycloheximide that extend the period of inhibition before conditioning do not affect the CR.

Conditioning between two injections. This experiment was designed to test whether conditioning under the influence of the inhibitor with a subsequent extended period of protein synthesis inhibition in the brain would have an effect on LTM formation. In this experimental series, all animals were treated according to the same schedule: the injections of cycloheximide were performed $1 \mathrm{hr}$ before and $3 \mathrm{hr}$ after conditioning. The bees were tested at $8 \mathrm{hr}$ and $24 \mathrm{hr}$ after training. Figure 5 shows that there is no significant difference ( $\chi^{2}$ test) between the cycloheximideinjected and Ringer-injected animals, demonstrating that cycloheximide has no inhibitory effect on the CR. The reduction of the CR over long periods of time ( $24 \mathrm{hr}$ ) is small and similar in both groups and in the range expected from all the other experiments (compare with Figs. 2-4).

\section{Discussion}

Since von Frisch's $(1914,1922)$ experiments, it is known that bees quickly learn colors and odors as food signals, and that they develop a stable and long-lasting memory (see Menzel, 1987, 1990, for review). Appetitive odor conditioning of the PER (proboscis extension response) is a very convenient situation for studying associative memory because odor learning is an associative phenomenon (Bitterman et al., 1983) and the memory lasts for as long as the bee survives in the metal tube to which it is fixed (Menzel, 1990). The striking advantages of this forward conditioning procedure are the short duration of a single CS/US pairing (a few seconds), the possibility of short intertrial intervals during multiple conditioning, the fast ac-

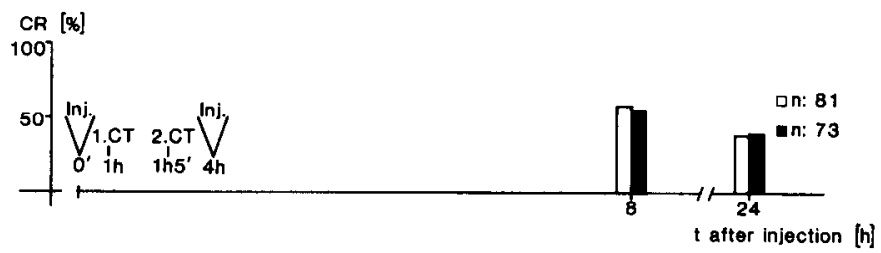

Figure 5. Conditioning between 2 injections of cycloheximide: CR of cycloheximide-injected bees $(\square)$ and Ringer controls $(\square)$ at two times after (the first) injection (Inj.). The second injection was performed 4 $\mathrm{hr}$ after the first injection; the conditioning (1.CT, 2.CT), $1 \mathrm{hr}$ after the first injection. Each bee was tested at different times.

quisition, and the high resistance to extinction during repetitive CS exposures without US prescntation (Bitterman ct al., 1983).

Amnestic treatments (local cooling of specific regions of the brain, electroconvulsive shocks) revealed that the formation of memory following a single conditioning trial is susceptible to such interference only during the first $7 \mathrm{~min}$ after conditioning, but not later (Menzel et al., 1974; Masuhr, 1976; Erber et al., 1980; Menzel and Sugawa, 1986). With multiple conditioning trials, there is no such early sensitive phase (Erber, 1976), and the memory lasts for the lifetime of the animal (Menzel, 1968). Therefore, one can infer that, as a basis for the experiments reported here, the consolidation of an early sensitive memory phase is transferred into a stable, unsusceptible, and long-lasting memory phase within a few minutes of conditioning (for review, see Menzel, 1990). For the honeybee, this amnesia-resistant memory is defined as LTM.

The results of the 4 experimental series reported here demonstrate that, with respect to the period analyzed, neither acquisition nor memory is distorted under the influence of the protein synthesis inhibitor cycloheximide. A result of this kind faces the general problem of any negative result in science, namely, that it carries less persuasive power with it than a positive result. Minor components of the experimental design may have a greater impact on the result. It is therefore of utmost importance to examine critically the experimental design and the control experiments. There is also always the possibility that the small amount of residual protein synthesis (less than about $5 \%$ ) may be responsible for the formation of LTM. It should be recognized, however, that the same procedure applied in other studies led to positive results; that is, it resulted in inhibitory effects on the trained behaviors. It is therefore tempting to conclude that the formation of LTM after olfactory PER conditioning does not depend on brain protein synthesis. Several arguments have to be addressed to confirm this hypothesis.

\section{Intensity and duration of protein synthesis inhibition}

As was shown in the first section of the Results (Protein synthesis), a single injection of cycloheximide into the brain leads to more than $90 \%$ inhibition over a period of at least $4 \mathrm{hr}$. With two injections, separated by 3 or $4 \mathrm{hr}$, the period of maximal inhibition was probably extended to at least $7 \mathrm{hr}$. Therefore, it is unlikely that the missing amnestic effect on behavior was due to insufficient intensity and duration of protein synthesis inhibition, though we cannot exclude by our experiments that a minimal rate of protein synthesis left after cycloheximide treatment is sufficient to retain olfactory LTM formation. However, the results of an independent study that addressed the same questions raised in our work support our conclusion (T. Tobin, personal communication): fluorograms of labeled brain proteins 
separated by SDS-PAGE did not show that the synthesis of every polypeptide was strongly reduced by cycloheximide treatment to the same extent, which indicates that the synthesis of all proteins was strongly reduced in the presence of cycloheximide.

From other studies it is not yet clear which factor, intensity or duration, is the more decisive component of blocking. With studies on mice, Flood et al. (1973) found that the number of amnestic animals increased with the increasing duration of inhibition. In contrast, Quinton and Kramarcy (1977) stated that the percentage of amnestic animals solely depended on the degree of inhibition at the time of training.

\section{Time of injection}

Another important factor is the time of cycloheximide injection with respect to the time of training. In studies with mice, an amnestic effect was observed after application of the inhibitor 30 min before conditioning (Randt et al., 1971). However, Quartermain and McEwen (1970) observed an amnestic effect when mice were injected $6 \mathrm{hr}$ after conditioning, and the amnestic behavior showed a clear dependence on the time of injection.

Studies on invertebrates do not imply that there is a common time window during which the inhibitor has to be applied. An inhibitory effect on long-term adaptation in crayfish was achieved with injections up to $6 \mathrm{hr}$ before training (Nguyen and Atwood, 1990). Long-term sensitization in Aplysia was successfully blocked when the inhibitor was applied $1 \mathrm{hr}$ before presentation of the sensitizing stimuli (Montarolo et al., 1986).

These studies do not allow the prediction of the optimal time of cycloheximide activity in the honeybee. For this reason, the time of injection was varied with respect to the conditioning, covering a period of $3 \mathrm{hr}$ beforc and $3 \mathrm{hr}$ after conditioning. In addition, this long period of inhibition ensured that, even with a limited knowledge of the exact beginning of LTM formation, a very brief period requiring protein synthesis would have been detected.

Therefore, it can be excluded that the protein synthesis inhibitor was not applied at the right time.

\section{Time of testing}

In all experimental series, several repeated tests were performed. One might argue that repeated testing weakens the memory trace. However, it is known from different studies using the olfactory PER conditioning that extinction is a very slow and ineffective process (Bitterman et al., 1983; Menzel, 1987, 1990). This is confirmed by the results reported here. The time of testing after conditioning was chosen to detect possible early defects by testing shortly after conditioning, and to detcct longlasting memory defects by testing $24 \mathrm{hr}$ after conditioning. At least with the $24 \mathrm{hr}$ test after repeated conditioning trials, one can be sure to obtain a measurement of LTM (for review, see Menzel, 1990).

\section{Associative strength of training}

Regarding the strength of training, there are again different statements. Flood et al. (1975b) found that with a smaller number of learning trials the amnestic effect became more pronounced in mice. On the other hand, Squire and Barondes (1973) showed that even with maximal associative strength (15-20 learning trials) the conditioned behavior could be blocked by cycloheximide.

For honeybees, it is known that a single PER-conditioning trial leads to a high learning rate and that three conditioning trials lead to maximal associative strength and a stable longlasting memory. To avoid possible decrements of the CR due to the injection, two conditioning trials were used throughout the experiments described here. Therefore, it is unlikely that the associative strength achieved by the two learning trials was not appropriate to establish a long-lasting and stable memory. Indeed, the tests after $24 \mathrm{hr}$ prove that the memory is only slightly weaker than at shorter time intervals after training.

\section{Kind of training}

The kind of applied conditioning procedure seems to be a decisive factor for LTM formation. In studies on mice, Bennett et al. (1972) used different forms of conditioning and obtained, under the same inhibitory conditions, different amnestic effects. This training dependency was supported by Stäubli et al. (1985). A training-dependent amnesia could mean that there are different forms of LTM, but not every form would require protein synthesis. Furthermore, it could be possible that the amnestic effects reported so far are due to other disturbing effects of cycloheximide rather than to inhibition of cerebral protein synthesis. For cycloheximide, a number of side effects and a high toxicity are well known (Segal et al., 1971; Flexner et al., 1973; Flood et al., 1973; Randt et al., 1973; Quartermain and Botwinick, 1975).

For the experiments described here, toxic effects and side effects of cycloheximide can be excluded. After injection, no influence on the behavior of both free-flying foragers $(S$. Wittstock, unpublished observation) and restrained bees could be observed. The mortality was not different for cycloheximideinjected animals and Ringer-injected control animals.

Further behavioral experiments applying learning paradigms of a different kind and complexity are necessary to address the question of whether the kind of training is a decisive factor for the amnestic effect after cycloheximide treatment.

\section{Conclusion}

Discussion of the various arguments leads to the conclusion that the formation of LTM after PER conditioning in the honeybee is independent of de novo protein synthesis.

Despite the common notion that the formation of LTM rcquires protein synthesis, some ideas about LTM formation without protein synthesis have already been formulated. Crick (1984), for example, argues that it would be possible to prevent degradation of a specialized synaptic macromolecule, which might be necessary for the maintenance of LTM, by a different timedependent turnover of the monomers of which it is composed. Kennedy (1988) suggests that one or more protein kinases could be responsible not only for the induction of long-term potentiation in the hippocampus but also for its maintenance, for example, by long-term activation of a specific protein kinase through phosphorylation or autophosphorylation. Lisman (1989) postulates a self-amplifying system for information storage via a so-called Hebb and anti-Hebb mechanism, using calmodulin kinase as an example. Müller and Spatz (1989) point out that in Drosophila, a brief increase of the cellular cAMP level can induce long-lasting protein kinase activity. These models do not argue against a dependence of LTM on protein synthesis (Frost et al., 1985; Goelet et al., 1986; Greenberg et al., 1987), but offer alternative possibilities.

The results presented here argue strongly for mechanisms other than de novo protein synthesis as a mechanism of LTM, and may thus help contribute insight into the cellular and mo- 
lecular pathways underlying the formation of long-lasting memory.

\section{References}

Agranoff BW, Davis RE, Brink JJ (1966) Chemical studics on memory fixation in the goldfish. Brain Res 1:303-309.

Alkon DL, Bank B, Naito S, Chen C, Ram J (1987) Inhibition of protein synthesis prolongs $\mathrm{Ca}^{2+}$-mediated reduction of $\mathrm{K}^{+}$currents in molluscan neurons. Proc Natl Acad Sci USA 84:6948-6952.

Bailey $\mathrm{CH}$, Chen M (1983) Morphological basis of long-term habituation and sensitization in Aplysia. Science 220:91-93.

Bailey CH, Chen M (1988) Long-term memory in Aplysia modulates the total number of varicosities of single identified sensory neurons. Proc Natl Acad Sci USA 85:2373-2377.

Barondes SH, Cohen HD (1967) Comparative effects of cycloheximide and puromycin on cerebral protein synthesis and consolidation of memory in mice. Brain Res 4:44-51.

Barraco RA, Lovell KL, Eisenstein EM (1981) Effects of cycloheximide and puromycin on learning and retention in the cockroach, Periplaneta americana. Pharmacol Biochem Behav 15:489-494.

Bennett EL, Orme A, Hebert M (1972) Cerebral protein synthesis inhibition and amnesia produced by scopolamine, cycloheximide, streptovitacin A, anisomycin and emetine in rat. Fed Proc 31:838.

Bergold PJ, Sweatt JD, Winicov J, Weiss KR, Kandel ER, Schwartz JH (1990) Protein synthesis during acquisition of long-term facilitation is needed for the persistent loss of regulatory subunits of Aplysia cAMP-dependent protein kinase. Proc Natl Acad Sci USA 87:37883791.

Bitterman ME, Menzel R, Fietz A, Schäfer S (1983) Classical conditioning of proboscis extension in honeybees (Apis mellifera). $\mathrm{J}$ Comp Psychol 97:107-119.

Brandon JG, Coss RG (1982) Rapid dendritic spine stem shortening during one-trial learning: the honeybee's first orientation flight. Brain Res 252:51-61.

Crick F (1984) Memory and molecular turnover. Nature 312:101.

Crow T, Forrester J (1990) Inhibition of protein synthesis blocks longterm enhancement of generator potentials produced by one-trial in vivo conditioning in Hermissenda. Proc Natl Acad Sci USA 87:44904494.

Davis HP, Spanis CW, Squire LR (1976) Inhibition of cerebral protein synthesis: performance at different times after passive avoidance training. Pharmacol Biochem Behav 4:13-16.

Eisenstein EM, Altman HJ, Barraco DA, Barraco RA, Lovell KL (1983) Brain protein synthesis and memory: the use of antibiotic probes. Fed Proc 42:3080-3085.

Erber J (1976) Retrograde amnesia in honeybees (Apis mellifera carnica). J Comp Physiol Psychol 90:41-46.

Erber J, Masuhr T, Menzel R (1980) Localization of short-term memory in the brain of the bee, Apis mellifera. Physiol Entomol 5:343358.

Eskin A, Garcia KS, Byrne JH (1989) Information storage in the nervous system of Aplysia: specific proteins affected by serotonin and cAMP. Proc Natl Acad Sci USA 86:2458-2462.

Fifkova E, van Harreveld A (1978) Changes in the dendritic spines of the dentate molecular layer during conditioning. Soc Neurosci Abstr 4:257

Fifkova E, Anderson CL, Young SJ, van Harreveld A (1982) Effect of anisomycin on stimulation-induced changes in dendritic spines of the dentate granule cells. J Neurocytol 17:183-210.

Flexner LB, Flexner JB, de la Haba G, Roberts RB (1965) Loss of memory as related to inhibition of cerebral protein synthesis. J Neurochem 12:535-541.

Flexner LB, Flexner JB, Roberts RB (1967) Memory in mice analyzed with antibiotics. Science 155:1377-1383.

Flexner LB, Serota RG, Goodman RH (1973) Cycloheximide and acetoxycycloheximide: inhibition of tyrosine hydroxylase activity and amnestic effects. Proc Natl Acad Sci USA 70:354-356.

Flood JF, Bennett EL, Rosenzweig MR, Orme AE (1973) The influence of duration of protein synthesis inhibition on memory. Physiol Behav 10:555-562.

Flood JF, Bennett EL, Orme AE, Rosenzweig MR (1975a) Effects of protein synthesis inhibition on memory for active avoidance training. Physiol Behav 14:177-184.

Flood JF, Bennett EL, Orme AE, Rosenzweig MR (1975b) Relation of memory formation to controlled amounts of brain protein synthesis. Physiol Behav 15:97-102.

Frost WN, Castellucci VF, Hawkins RD, Kandel ER (1985) Monosynaptic connections made by the sensory neurons of the gill- and siphon-withdrawal reflex in Aplysia participate in the storage of longterm memory for sensitization. Proc Natl Acad Sci USA 82:82668269.

Gibbs ME, Ng KT (1977) Psychobiology of memory: towards a model of memory formation. Biobehav Rev 1:113-136.

Goelet P, Castellucci VF, Schacher S, Kandel ER (1986) The long and the short-term memory-a molecular framework. Nature 322:419422 .

Greenberg SM, Castellucci VF, Bayley H, Schwartz JH (1987) A molecular mechanism for long-term sensitization in Aplysia. Nature 329: $62-65$.

Hyden H, Lange PW (1970) Brain-cell protein synthesis specifically related to learning. Proc Natl Acad Sci USA 65:898-904.

Kaatz HH, Hagedorn HH, Engels W (1985) Culture of honey bee organs: development of a new medium and the importance of tracheation. In vitro Cell Dev Biol 21:347-352.

Kennedy MB (1988) Synaptic memory molecules. Nature 335:770772.

Kuwabara M (1957) Bildung des bedingten Reflexes von Pavlovs Typus bei der Honigbiene, Apis mellifica. J Faculty Sci Hokkaido Univ $458-464$.

Lindauer M (1963) Allgemeine Sinnesphysiologie. Orientierung im Raum. Fortschr Zool 16:58-140.

Lisman J (1989) A mechanism for the Hebb and the anti-Hebb processes underlying learning and memory. Proc Natl Acad Sci USA 86: 9574-9578.

Masuhr T (1976) Lokalisation und Funktion des Kurzzeit-Gedächtnisses der Honigbiene, Apis mellifica. PhD thesis, TH Darmstadt (Germany).

Menzel R (1968) Das Gedächtnis der Honigbiene für Spektralfarben. Z Vgl Physiol 60:82-102.

Menzel R (1987) Memory traces in honeybees. In: Neurobiology and behavior of honeybees (Menzel R, Mercer A, eds), pp 310-325. Berlin: Springer.

Menzel R (1990) Learning, memory and "cognition" in honey bees. In: Neurobiology of comparative cognition (Kesner RP, Olton DS, eds), pp 237-292. London: Erlbaum.

Menzel R, Erber J (1972) The influence of the quantity of reward on the learning performance in honeybees. Behavior 41:27-42.

Menzel R, Sugawa M (1986) Time course of short-term memory depends on associative events. Naturwissenschaften 73:564-565.

MenzeL R, Erber J, Masuhr T (1974) Learning and memory in the honeybee. In: Experimental analysis of insect behaviour (Barton-Brown L, ed), pp 195-217. Berlin: Springer.

Menzel R, Michelsen DB, Rüffer P, Sugawa M (1988) Neuropharmacology of learning and memory in honeybees. In: NATO ASI Series $\mathrm{H} 19$, Modulation of synaptic transmission and plasticity in nervous systems (Hertting G, Spatz HC, eds), pp 67-81. Berlin: Springer.

Menzel R, Wittstock S, Sugawa M (1990) Chemical codes of learning and memory in the honey bee. In: The biology of memory (Squire L, Lindenlaub K, eds), pp 335-360. Stuttgart: Schattauer.

Michelsen DB (1988) Catecholamines affect storage and retrieval of conditioned odour stimuli in honey bees. Comp Biochem Physiol 91: 479-482.

Michelsen DB, Menzel R (1984) Die Wirkung von Catecholaminen auf den Lernvorgang der Honigbiene. Verh Dtsch Zool Ges 77.

Montarolo PG, Goelet P, Castellucci VF, Morgan J, Kandel ER, Schacher S (1986) A critical time window for macromolecular synthesis in long-term heterosynaptic facilitation in Aplysia. Science 234:12491254.

Müller U, Spatz HC (1989) $\mathrm{Ca}^{2+}$-dependent proteolytic modification of the cAMP-dependent protein kinase in Drosophila wild-type and dunce memory mutants. J Neurogenet 6:95-114.

Nguyen PV, Atwood HL (1990) Expression of long-term adaptation of synaptic transmission requires a critical period of protein synthesis. J Neurosci 10:1099-1109.

Patel SN, Stewart MG (1988) Changes in the number and structure of dendritic spines 25 hours after passive avoidance training in the domestic chick, Gallus domesticus. Brain Res 449:34-46.

Patel SN, Rose SPR, Stewart MG (1988) Training induced dendritic spine density changes are specifically related to memory formation processes in the chick, Gallus domesticus. Brain Res 463:168-173. 
Quartermain D, Botwinick CY (1975) Role of biogenic amines in the reversal of cycloheximide-induced amnesia. J Comp Physiol Psychol 88:386-401.

Quartermain D, McEwen BS (1970) Temporal characteristics of amnesia induced by protein synthesis inhibitor: determination by shock level. Nature 228:677-678.

Quinton EE, Kramarcy NR (1977) Memory impairment correlates closely with cycloheximide dose and degree of inhibition of protein synthesis. Brain Res 131:184-190.

Randt CT, Barnett BM, McEwen BS, Quartermain D (1971) Amnesic effects of cycloheximide on two strains of mice with different memory characteristics. Exp Neurol 30:467-474.

Randt CT, Korein J, Levidow L (1973) Localization of action of two amnesia producing drugs in freely moving mice. Exp Neurol 41:628634.

Segal DS, Squire LR, Barondes SH (1971) Cycloheximide: its effects on activity are dissociable from its effects on memory. Science 172 : 82-84.

Squire LR, Barondes SH (1973) Memory impairment during prolonged training in mice given inhibitors of cerebral protein synthesis. Brain Res 56:215-225.
Squire LR, Barondes SH (1974) Anisomycin, like other inhibitors of cerebral protein synthesis, impairs "long-term" memory of a discrimination task. Brain Res 66:301-308.

Squire LR, Davis HP (1975) Cerebral protein synthesis inhibition and discrimination training: effects of extent and duration of inhibition. Behav Biol 13:49-57.

Stäubli U, Faraday R, Lynch G (1985) Pharmacological dissociation of memory: anisomycin, a protein synthesis inhibitor, and leupeptin, a protease inhibitor, block different learning tasks. Behav Neural Biol 43:287-297.

Vareschi E (1971) Duftunterscheidung bei der Honigbiene-Einzelzellableitungen und Verhaltensreaktionen. Z Vgl Physiol 66:22-26.

von Frisch K (1914) Der Farbensinn und Formensinn der Bienc. Zool Jahrb Teil Physiol 35:1-188.

von Frisch K (1922) Methoden sinnesphysiologischer und psychologischer Untersuchungen an Bienen. In: Handbuch der biologischen Arbeitsmethoden (Abderhalden E, ed), pp 21-49. Berlin: Urban \& Schwarzenberg. 